\title{
Factors Affecting the Innovative Paddy Cultivation and Marketing (Thanjavur District)
}

\author{
A.Elangovan, N.Bharathi
}

\begin{abstract}
Paddy (rice) is the most important one, especially in countries like India. Indian States Tamil Nadu is majority states which cultivate paddy in Cauvery Delta Region. Thanjavur is one of leading district in paddy cultivation Since last decade has not shown any significant improvement. Results and finding :lack of awareness among the labours is first rank of identifying in the study area with gthe mean score of 65.44 because the workers are not skill with this new method are SRI method.next majour problem of weed control and strain in use of cono weeder with the mean score are 61.64 and 57.39 respectively describes that Demanding Sample paddy at Free of Cost and High Dominance of Market Intermediaries are the major factors influencing the Problems in market with the highest mean score of 63.08and 61.97 High Commission Charged 60.02 and Credit Sales 57.83 are identified as the next major reasons for Problems in market by Market Intermediaries and they are ranked third and fourth respectively. Reasons such us Lack of Consultation Before Price Fixation, Demanding paddy beyond Actual Weight are ranking fifth, sixth, respectively. The research paper concluded that cultivation of paddy is a profitable enterprises in the study area Around three percent of the harvested paddy was being lost at firm itself farmers realized higher profits when they sold their paddy produce through Governments direct procurement. centers , hence channel was more efficient that other channels. The major marketing constraints faced the producers (or farmers) in the study area were higher marketing cost, the distant location of DPC" and lack of awareness on market information and market intelligences services, services, Farmers should be educated and trained on post harvest operations that would greatly help them to reduce the post - harvest losses in rice, Further delay in weighing and payment are to be avoided in the Direct Procurement Centers (DPC) so as to encourage farmers to take up efficient production decision for the next season. The agro department organized most awareness and training program provided to farmers and develop innovative methods of paddy cultivation.
\end{abstract}

Keywords :Paddy, Farmers . SRI method, Market Intermediaries.

\section{INTRODUCTION}

\subsection{Introduction}

Agriculture constitutes the nerve centre of all economic activities in countries - both developed ${ }^{1}$ and under-developed - all over the world. In fact the very survival of mankind depends exclusively on the myriad varieties of food grains produced. Of the many kinds of food grain available, paddy (rice) is the most important one, especially in countries like India. Hence, a place of paramount significance has been given to the acceleration and growth of paddy cultivation during the plan periods. This is precisely the

Revised Manuscript Received on October 22, 2019.

Dr. A.Elangovan, Professor \& Head, Department of Commerce ,Periyar University, Salem 636011

N.Bharathi, Ph,D Research Scholar, Department of Commerce ,Periyar University, Salem 636011

Email: bharathi.kannan_123@yahoo.com reason why the production and marketing of paddy has turned out to be a veritable avenue of research for both explorative and innovative thinkers in recent years. the Indian States Tamil Nadu is highest states which cultivate paddy in Cauvery Delta Region.. thanjavur is one of leading district in paddy cultivation Since last decade has not shown any significant improvement Various efforts of attitude of their farming such us high yielding varieties of paddy, System of Rice Interfication method, increasing fertilizers coupled with develop package have been made in resent 10 years through varieties of centrally sponsoring schemes but the paddy farmers not free from various producing and marketing problems. Bearing the above points in mind the present research paper makes an attempt to study on 'Factors Affecting the Innovative Paddy Cultivation and Marketing in Thanjavur district of Tamil Nadu.

\subsection{Operational Definitions}

According to Thomson - the study of Agriculture marketing comprises all the operation and the agencies conducting them involved in the movement of farm produced foods, raw materials and their derivatives such as textiles, from the farm to final consumers and the effects of such operation on farmers, middlemen and consumers.Agricultural marketing is the study of all the activities, agencies and agricultural products from the farms to the consumers

\subsection{Review of Literature}

Albert Samwel Moshi (2013) ${ }^{1}$ has done a study on "Analysis Of Rice Marketing Systems In Mpanda District Of Tanzania" The study objective are to examine the rice marketing chain in Mpanda district of Tanzania. Specifically, the study intended to carry out the value chain mapping; analyse economic efficiency of rice marketing system; assessing the distribution of gains and; examine the competitiveness criteria of rice marketing chain. The methodology was adopted for the study used primary data used information collected from four wards, 120 rice cultivators selected through interview schedule namely transporters, wholesalers, millers, retailers and consumers. Data analysis involved different techniques such as actors' linkage matrix, marketing margin and profitability analyses. this study found that wholesalers enjoy the biggest share of the selling margin, where at cross boundary markets, the wholesalers' profit goes as higher as Tsh. $821 / \mathrm{kg}$ as compared to Tsh. $533 / \mathrm{kg}$ which is the price received by farmers. This study reveled unequal distribution of benefits among actors, the trader is eat for farmers profit the study was recommended and concluded that Credit facility is highly recommended to farmers especially in rural areas. Farmers are lacking collaterals and commercial financial institutions are not ready to offer credits to 
risky businesses like agriculture and then improvement of effectiveness of warehouse receipt system and village markets in order to secure high prices during off-season.. ${ }^{2}$ The approach used by Asians in bringing agriculture forefront during green revolution, should be used if we want to commercialize agriculture. Credits will enable farmers to increase acreage, and many traders to engage themselves in marketing associated activities like processing and packaging. Furthermore, lack of adequate agricultural infrastructure and market information systems was observed to be critical areas of policy concerns. the government policies should provide for microcredit institution on provision of credit to rural farmers are recommended improve productivity by small land holder farmers to use modern agriculture technology.

Anandaraj. P (2013) This study analyzed marketing systems of paddy available for farmers in Thiruvarur district. the objectives of the study to analysis terms of marketing channels, marketing cost, marketing margin, price spread and marketing efficiency. The Sample consists of 600 farmers who have been classified as small and large farmers according to their land holdings. Proportionate random sampling technique was adopted. In order to identify the key factors of marketing paddy in the study area, a Multiple Linear Regression Model, Garrett's Ranking Technique, Shepherd's Formula, Acharya and Agarwal's Formula and Composite Index Methods were used. The structural differences between small and large farmers were tested by using Chow's F-test. The results revealed the importance of middle man in the chain of marketing that starts with the producer and ends with the consumer. The study has also elucidate fruitful suggestions for the betterment of the farmers, to encourage Government machinery and to avoid exploitations of middle man of Thiruvarur District , TamilNadu.

\subsection{Scope and Importance of the Study}

This study analyzed Thanjavur district . The district is highest paddy cultivation in the Tamil Nadu districts. this study focused on farmers faced problems of innovative paddy cultivation as well as identifying marketing problem of intermediaries in the study area .

\subsection{Objective of the study}

To measure the modern farming method and identifying problems of modern farming.

2 1. Albert Samwel Moshi (2013) Analysis Of Rice Marketing Systems In Mpanda District Of Tanzania A dissertation submitted in partial fulfillment of the requirements for the degree of master of science in agricultural economics of sokoine university of agriculture. Morogoro, tanzania. International2013

Dr. Anandaraj. P (2013) Cost, Returns and Marketing Channels of Paddy in Thiruvarur District (Tamil Nadu) International Journal of Science and Research (IJSR) ISSN (Online): 2319-7064 Index Copernicus Value (2013): 6.14 | Impact Factor (2014): 5.611 Volume 4 Issue 11, November 2015 www.ijsr.net
To identifying the farmers problems of paddy marketing about intermediaries.

\subsection{Research Methodology}

\subsubsection{Sampling Techniques}

Primary data were collected from seven districts (Thanjavur, Nagappattinum, Thiruvarur,Trichy,Perambalur, Cuddalore, Pudukkottai ) in which 50 paddy producers were selected through convenience sampling method.

Statistical Tools Used

$$
\text { * Percentage Analysis }
$$

\section{Percentage analysis}

TABLE.1

\begin{tabular}{|c|c|c|c|}
\hline \multirow{3}{*}{ Gender } & $\begin{array}{l}\text { Demographic } \\
\text { Profile }\end{array}$ & $\begin{array}{l}\text { No of } \\
\text { respondent }\end{array}$ & Percent \\
\hline & $\begin{array}{l}\text { Male } \\
\text { Female }\end{array}$ & $\begin{array}{l}48 \\
2\end{array}$ & $\begin{array}{l}96.0 \\
4.0\end{array}$ \\
\hline & Total & 50 & 100.00 \\
\hline \multirow[t]{2}{*}{ Age } & $\begin{array}{l}31-40 \text { years } \\
41-50 \text { years } \\
51 \text { years and } \\
\text { above }\end{array}$ & $\begin{array}{l}10 \\
15 \\
25\end{array}$ & $\begin{array}{c}20 \\
30 \\
50\end{array}$ \\
\hline & Total & 50 & 100 \\
\hline \multirow[t]{2}{*}{ Education } & $\begin{array}{l}\text { Illiterate } \\
\text { Up to S.S.L.C } \\
\text { H.sc } \\
\text { Degree and } \\
\text { Above }\end{array}$ & $\begin{array}{l}12 \\
20 \\
13 \\
5\end{array}$ & $\begin{array}{l}24.0 \\
40.0 \\
26.0 \\
10.0\end{array}$ \\
\hline & Total & 50 & 100.0 \\
\hline $\begin{array}{l}\text { Paddy } \\
\text { Experience }\end{array}$ & $\begin{array}{l}6 \text { to } 10 \text { yeras } \\
11 \text { to } 20 \text { years } \\
21 \text { yearss and } \\
\text { above }\end{array}$ & $\begin{array}{l}9 \\
28 \\
13\end{array}$ & $\begin{array}{l}18.0 \\
56.0 \\
26.0\end{array}$ \\
\hline & Total & 50 & 100.0 \\
\hline $\begin{array}{ll}\text { Adoption } & \text { for } \\
\text { New } & \\
\text { Technology } & \text { of } \\
\text { paddy } & \\
\text { cultivation } & \end{array}$ & $\begin{array}{l}\text { SRI Method } \\
\text { Traditional } \\
\text { Method }\end{array}$ & $\begin{array}{l}15 \\
35\end{array}$ & $\begin{array}{l}30.0 \\
70.0\end{array}$ \\
\hline & Total & 50 & 100.0 \\
\hline $\begin{array}{l}\text { Farm } \\
\text { Machineries } \\
\text { Owned by the } \\
\text { Paddy Farmers }\end{array}$ & $\begin{array}{l}\text { Yes } \\
\text { No }\end{array}$ & $\begin{array}{l}12 \\
28\end{array}$ & $\begin{array}{l}24.0 \\
76.0\end{array}$ \\
\hline & Total & 50 & 100.0 \\
\hline
\end{tabular}

Respondent Personal Details

Source: Primary Data

\section{Inference:}

The above table shows respondents personal details of the cultivation and marketing of paddy. The study taken 50 Cultivators, $96.00 \%$ are male farmers and $4.9 \%$ are female farmers. - Majority of respondents (96.00)are male farmers to preferred the 
cultivation of paddy in the Cauvery delta region.

The predominant age group of the respondents ( 20 per cent) is 31-40 years. A good majority of the remaining respondents are distributed in the age group above 51 years to preferred the cultivation of paddy in the Cauvery delta region. $30 \%$ of the respondents are distributed in the age groups upto 41-50 years respectively. The highest literacy rate $(40 \%)$ of the respondents is SSLC level. 26 per cent of the respondents have got upto H.sc education and 10 per cent have got degree and above education. 24per cent of the respondents are illiterates. the majority of the farmers( $40 \%)$ education qualification is SSLC level. 56per sent of the respondents have farming expireance11-20 years. 26per sent of the respondents have 21 years and above for experience for farming. $18 \%$ of the respondents have farming experience is 6-10 years. the majority of the farmers $(56 \%)$ have $11-20$ years framing experience in the study area. the . the majority $(70 \%)$ of the paddy farmers to adopted traditional method . least farmers( $30 \%)$ to adopted innovated method of SRI paddy cultivation . the majority of the farmers $(56 \%)$ have not own Farm Machines used for Hire Farm Machineries most of the farmers are not able to buy those machineries, though loans are available for this purpose, and instead they hire those machineries.

\section{II. -GRANTEE RANKING METHOD}

TABLE -2

Problem of SRI Paddy Cultivation

\begin{tabular}{|c|c|c|c|c|}
\hline S.NO & SRI Problems & $\begin{array}{l}\text { Total } \\
\text { Score }\end{array}$ & $\begin{array}{l}\text { Mean } \\
\text { Score }\end{array}$ & Rank \\
\hline$\overline{1}$ & Weed control problem & 6164.53 & 61.64 & II \\
\hline 2 & $\begin{array}{c}\text { Requires skilled labour } \\
\text { management }\end{array}$ & 5438.44 & 53.48 & IV \\
\hline 3 & Lack of skilled labourers & 5133.45 & 51.32 & VI \\
\hline 4 & $\begin{array}{c}\text { Problem of mechanical } \\
\text { weeder availability }\end{array}$ & 5267.41 & 52.76 & $\overline{\mathrm{V}}$ \\
\hline 5 & Water management & 4441.40 & 44.41 & VII \\
\hline$\overline{6}$ & Strain in use of Cono weeder & 5736.00 & 57.39 & III \\
\hline 7 & $\begin{array}{c}\text { Lack of awareness among the } \\
\text { labours }\end{array}$ & 6542.66 & 65.44 & $\overline{\mathrm{II}}$ \\
\hline 8 & $\begin{array}{c}\text { Lack of technical support } \\
\text { from officials }\end{array}$ & 44415.62 & 44.36 & "VIII \\
\hline 9 & $\begin{array}{l}\text { Handling the seedling of } 8 \text { to } \\
12 \text { days }\end{array}$ & 4342.00 & 43.42 & IX \\
\hline 10 & Unsuitability of land & 2482.26 & 24.81 & $\bar{X}$ \\
\hline
\end{tabular}

Source: Primary Data

\section{Inferences:}

The table shows that lack of awareness among the labours is first rank of identifying in the study area with gthe mean score of 65.44 because the workers are not skill with this new method are SRI method.next majour problem of weed control and strain in use of cono weeder with the mean score are 61.64 and 57.39 respectively and followed by required skilled labour management, mechanical weeder avability, lack of skill labour, water management, lack of technical support from official are ranked fourth, fifth, sixth, seventh. eighth ranked faced by the problems of SRI method and unsuitable and handling the seeding of 8 to 12 days and unsuitable of land are considered as the least problems faced by the sri paddy farmers.

\section{TABLE -3}

\section{Marketing Problems while in market by Market}

\section{Intermediaries}

\begin{tabular}{|c|c|c|c|c|}
\hline Sl.No & $\begin{array}{c}\text { Problems of } \\
\text { Market } \\
\text { Intermediaries }\end{array}$ & $\begin{array}{l}\text { Total } \\
\text { Score }\end{array}$ & $\begin{array}{l}\text { Mean } \\
\text { Score }\end{array}$ & Rank \\
\hline 1 & $\begin{array}{l}\text { High } \\
\text { Commission } \\
\text { Charged }\end{array}$ & 6002 & 60.02 & III \\
\hline 2 & $\begin{array}{l}\text { Lack of } \\
\text { Market } \\
\text { Information } \\
\text { from } \\
\text { Intermediaries }\end{array}$ & 5220 & 52.2 & VII \\
\hline 3 & $\begin{array}{l}\text { High } \\
\text { Dominance of } \\
\text { Market } \\
\text { Intermediaries }\end{array}$ & 6197 & 61.97 & II \\
\hline 4 & Credit Sales & 5783 & 57.83 & IV \\
\hline 5 & $\begin{array}{l}\text { Lack of } \\
\text { Consultation } \\
\text { Before Price } \\
\text { Fixation }\end{array}$ & 5638 & 56.38 & V \\
\hline 6 & $\begin{array}{l}\text { Demanding } \\
\text { Sample paddy } \\
\text { at Free of Cost }\end{array}$ & 6308 & 63.08 & I \\
\hline 7 & $\begin{array}{l}\text { Demanding } \\
\text { paddy beyond } \\
\text { Actual Weight }\end{array}$ & 5310 & 53.1 & VI \\
\hline
\end{tabular}

Source: Primary Data

Inference:

Table describes that Demanding Sample paddy at Free of Cost and High Dominance of Market Intermediaries are the major factors influencing the Problems in market by Market Intermediaries with the highest mean score of 63.08and 61.97 High Commission Charged 60.02 and Credit Sales 57.83 are identified as the next major reasons for Problems in market by Market Intermediaries and they are ranked third and fourth respectively. Reasons such us Lack of Consultation Before Price Fixation, Demanding paddy beyond Actual Weight are ranking fifth, sixth, respectively Problems of market by Market Intermediaries finally Lack of Market Information from Intermediaries are identified as 
the least influencing factors Marketing Problems while in market by Market Intermediaries with the lowest mean scores.

\section{FINDINGS}

1. Out of 50 respondents, 96.00 per cent are male least female farmers participated in agriculture activity in the study area.

2. . The most of the cultivator are distributed in the age group above 51 years to preferred the cultivation of paddy. least young farmers participated for cultivation attitude in the study area.

3. The majority literacy rate 40 per cent of the cultivators are SSLC level. $26 \%$ of the cultivators has got up to H.Sc education level. very few respondents are got degree level in the study area`

4. 56 per sent of the respondents have farming expireance11-20 years. 26per sent of the respondents have 21 years and above for experience for farming

5. The table shows that lack of awareness among the labours is first rank of identifying in the study area with gthe mean score of 65.44 because the workers are not skill with this new method are SRI method.next majour problem of weed control and strain in use of cono weeder with the mean score are 61.64 and 57.39 respectively

6. Table describes that Demanding Sample paddy at Free of Cost and High Dominance of Market Intermediaries are the major factors influencing the Problems in market by Market Intermediaries with the highest mean score of 63.08and 61.97 High Commission Charged 60.02 and Credit Sales 57.83 are identified as the next major reasons for Problems in market by Market Intermediaries and they are ranked third and fourth respectively. Reasons such us Lack of Consultation Before Price Fixation, Demanding paddy beyond Actual Weight are ranking fifth, sixth, respectively Problems of market by Market Intermediaries finanly Lack of Market

Information from Intermediaries are identified as the least influencing factors Marketing Problems while in market by Market Intermediaries with the lowest mean scores.

\section{Suggestion}

* The agriculture department provide more tanning programme and awareness of new modern cultivation

* The government encouraged to female farmers for provide more subsidiaries then male farmers.

* The government should encouraged young farmers in cultivation activity and provide pention scheme for farming attitude for life time.

* The study find out the government include agriculture and supply free labour for Mahatma Gandhi National Rural Employment Guarantee Scheme

* Agro department increases more female farmers participation in agriculture activities and give more subsidies than male farmers .

\section{CONCLUSION}

The research paper concluded that cultivation of paddy is a profitable enterprises in the study area Around three percent of the harvested paddy was being lost at firm itself farmers realized higher profits when they sold their paddy produce through Governments direct procurement. centers, hence channel was more efficient that other channels. The major marketing constraints faced the producers (or farmers) in the study area were higher marketing cost , the distant location of DPC" and lack of awareness on market information and market intelligences services, services, Farmers should be educated and trained on post harvest operations that would greatly help them to reduce the post harvest losses in rice, Further delay in weighing and payment are to be avoided in the Direct Procurement Centers (DPC) so as to encourage farmers to take up efficient production decision for the next season. The agro department organized most awareness and training program provided to farmers and develop innovative methods of paddy cultivation.

\section{REFERENCE}

* Albert Samwel Moshi (2013) Analysis Of Rice Marketing Systems In Mpanda District Of Tanzania A dissertation submitted in partial fulfillment of the requirements for the degree of master of science in agricultural economics of sokoine university of agriculture. Morogoro, tanzania. International2013

* Dr. Anandaraj. P (2013) Cost, Returns and Marketing Channels of Paddy in Thiruvarur District (Tamil Nadu) International Journal of Science and Research (IJSR) ISSN (Online): 2319-7064 Index Copernicus Value (2013): 6.14 | Impact Factor (2014): 5.611 Volume 4 Issue 11, November 2015 www.ijsr.net

* Web site: www.businessmanagementideas.com 